\title{
THE ASSISTED REPRODUCTIVE TECHNOLOGY SUBSIDY IN KOREA: CRITICISM FROM A PERSPECTIVE OF REPRODUCTIVE RESPONSIBILITY
}

\author{
Claire Junga Kim ${ }^{1}$
}

\begin{abstract}
The Korean government's new policy of subsidizing assisted reproductive technology (ART) fees to increase the birth rate reflects a lack of concern for future generations and their quality of life. It seems wrong to treat the future child as just a number that contributes to achieving the target birth rate, or as a mere means of solving a problem facing the current generation. However, when one tries to articulate the shortcomings of this new policy, one realizes that the ontological arguments surrounding this issue, namely the non-identity problem is complex. I propose the concept of reproductive responsibility as a response to the possible life. This concept presupposes a relationship between the reproductive agent and the possible new life. Since the concept draws the normative standard from that relationship, it resolves the non-identity problem and makes it possible to criticize the new policy of subsidizing ART.
\end{abstract}

Key words: reproduction, reproductive rights, reproductive responsibility, assisted reproductive technology

\section{El subsidio para la tecnología de reproducción asistida en Corea: crítica desde una perspectiva de responsabilidad reproductiva}

Resumen: La nueva política del gobierno de Corea de proporcionar subsidio para los costos de la tecnología de reproducción asistida (TRA), para incrementar el número de nacimientos, refleja falta de preocupación por las futuras generaciones y su calidad de vida. Parece equivocado tratar a un niño futuro como un número que contribuye a lograr la frecuencia de nacimientos objetivo, como un mero medio para resolver un problema que enfrenta la generación presente. Sin embargo, cuando uno trata de articular las deficiencias de esta nueva política, se da cuenta de que los argumentos ontológicos sobre el tema son complejos, principalmente el problema de falta de identidad. Propongo el concepto de "responsabilidad reproductiva" como respuesta a la posible vida. Este concepto presupone una relación entre el agente reproductivo y la posibilidad de nueva vida. Debido a que el concepto extrae su normatividad de esta relación, se resuelve el problema de falta de identidad y hace posible criticar la nueva política de proporcionar subsidio a TRA.

Palabras clave: reproducción, derechos reproductivos, responsabilidad reproductiva, tecnología de reproducción asistida

\section{A subvençáo tecnológica de reproduçáo assistida na Coreia: uma crítica a partir de uma perspectiva de} responsabilidade reprodutiva

Resumo: A nova política de governo coreano de subsidiar a tecnologia de reprodução assistida (ART) para aumentar a taxa de natalidade reflete uma falta de preocupação com a geração futura e sua qualidade de vida. Parece errado tratar a futura criança como apenas um número que contribui para atingir a meta de taxa de natalidade, ou como um mero meio de resolver um problema que enfrentam a atual geração. No entanto, quando tenta-se articular as deficiências desta nova política, percebe-se que os argumentos ontológicos em torno desta questáo, ou seja o problema da não-identidade é complexo. Eu proponho o conceito de responsabilidade reprodutiva como uma resposta para a vida possível. Este conceito pressupóe uma relação entre o agente reprodutivo e a possível nova vida. Uma vez que o conceito desenha um padrão normativo desta relação, ele resolve o problema da não-identidade e torna possível criticar a nova política de subsidiar ART.

Palavras-chave: reprodução, direitos reprodutivos, responsabilidade reprodutiva, tecnologia de reprodução assistida

\footnotetext{
${ }^{1}$ Department of Medical Education, College of Medicine, Ewha Womans University, Seoul, Republic of Korea Correspondence: clairejungakim@gmail.com
} 


\section{Introduction}

Since 2006, the Korean government has implemented the "National Support Program for Infertile Couples," which subsidizes artificial reproductive technology (ART), including in vitro fertilization (IVF) and in uterine insemination(IUI), for married couples. This program aims to address the low birth rate in Korea, which has emerged as a serious problem in Korean society along with the issues raised by aging. However, consumed by the fear of a future shortage of workers, the government fails to understand the impact of its intervention on women's bodies, and to demonstrate appropriate concern for female citizens and for the children who will be born of these women. The government has paid attention exclusively to how many babies are born, and it has failed to conduct any study that would address the quality of life of these newborns, i.e., follow-up studies on the health status of babies born through the IVF and IUI subsidy program and that of their mothers. With the figures showing a relatively large average number of embryo transfers in Korea compared to other countries (1) and frequent multiple births following IVF, it is reasonable to conclude that preterm birth and low birth weight, which are common in multiple pregnancies, have contributed to the recent increase in NICU admissions(2). According to its own claims, the subsidy program has resulted in the birth of children who would not have been born were it not for the program. Thus, the program has resulted in some negative health outcomes among newborns. Some believe that this policy harms the newborns. Moreover, the policy seems even worse since it treats a future child just as a number, contributing to the goal of a higher birth rate, i.e., a means to solving a problem facing the current generation. Besides looking at a big picture, the government need to consider the health problems of children that is caused by the policy

However, in attempting to articulate the shortcomings of this new policy, a complex ontological problem is raised: the non-identity problem. Although the subsidy program lacks appropriate concern for the quality of life of those who will be born due to its existence, it is impossible for the life in question to exist without the program. Therefore, it does not seem to be wrong, for the sake of the child, to bring him/her into the world by means of this program. This notion is contrary to our everyday thinking and common-sense judgment. We need a concept that resolves the nonidentity problem, making it possible to endow the new life with importance.

\section{The non-identity problem}

The non-identity problem arises when a reproductive action causes both human existence and a flaw in that existence at the same time and, furthermore, causes existence and the flaw in that existence in an inseparable way. With a 14-yearold girl's reproduction case, Parfit(3:358) presented the example of causing both negative life conditions and life itself.

This girl chooses to have a child. Because she is so young, she gives her child a bad start in life. Though this will have bad effects throughout this child's life, his life will, predictably, be worth living. If this girl had waited for several years, she would have given her child a better start in life.

Parfit pointed out that it is not possible to oppose the 14-year-old girl's reproduction for the sake of the child who will be born as the result of the act. According to Parfit, it is impossible for the child to complain by comparing his situation with the situation where he was born to a 24-year-old mother. He has to compare among the alternatives that would have been possible for him. Here, since the boy who would have been born to a 24-year-old mother is not the same person, the only alternative to his real life would be nonexistence. If, as Parfit presumes, life is better than nonexistence, the child cannot condemn his own birth.

Presupposed in defining non-identity as a problem is the comparative conception of harm and the condition of fixed identity, which is required because the comparison must be made among possible alternative experiences of a single individual(4). In the vignette for the non-identity problem, to decide whether the flaw that accompanies the creation of a life constitutes harm, one must compare the self-interest in each of the two possible alternatives for the very individual who actually has the flaw in one's life; self inter- 
est in the flawed life vs self interest of nonexistence. A classical non-identity problem, such as Parfit's case, sidesteps the fundamental problem. By adding the premise, "life will be worth living," the answer becomes inevitable that a flawed life is preferable to no life at all. So, the flawed life does not amount to harm. However, for the sake of discussion, let us not uncritically accept the unexamined premise about flawed life and nonexistence. If we reject that premise, we face another fundamental problem: one cannot compare two different options that an individual would experience because in one option, there is no existence to experience anything. In other words, having experienced only existence, we cannot know about nonexistence and, therefore, cannot compare existence and nonexistence. Therefore, the non-identity problem leads us to the point where we, at least on behalf of future children, cannot reach any conclusion.

To sum up, what makes non-identity problem $a$ problem is the premise that morally defective action can be understood through the concept of comparative harm and the resulting requirement that the comparison be between alternatives available to the same individual. These cause a real problem, both epistemologically and ontologically, when they are applied under the condition of nonexistence, which no one has experienced. Nonetheless, if we try to make a moral judgment about reproductive action, the premise and requirement are not actually necessary. Avoiding the premise, we can solve the non-identity problem and reach a moral judgment that is coherent with our intuition on reproductive actions. Moreover, we can develop directives regarding reproductive issues that are congruent with a larger moral system.

\section{Moral contractualism and reproductive action}

If we broaden our view from a comparative concept of harm to relationships, we can avoid the impossible exercise of comparing existence with nonexistence, and we can make moral judgments about reproductive actions. One way we can articulate the key moral requirement is to ask what we owe to each other, invoking Scanlon's moral contractualism(5:147-148) ${ }^{2}$. In moral contractualism, justifiability to others determines morality, i.e., what is right and what is wrong.

"It [contractualism] holds that an act is wrong if its performance under the circumstances would be disallowed by any set of principles related to the general regulation of behavior that no one could reasonably reject as a basis for informed, unforced general agreement" (5:153).

Presenting morality as the requirement of justifiability to others, Scanlon argues that the source of the power of this requirement is relationships with others. In other words, relationships that we enter by abiding by the moral requirement are in themselves appealing, and it is from this that the morality of right and wrong gains power. Since we have reason to want this ideal relationship of mutual recognition, we owe one another the requirement of justification as an expression of respect for the value of a person who has "reason assessing, self-governing" capacity(5:106).

Let us extend this theory of moral contractualism, which originally considered only existing people, to the issue of reproduction. A possible life $^{3}$ can deservedly enter into this relationship of mutual recognition that is the basis of morality, thereby earning the right to receive the justification of acts from other moral agents. The fact that mutual recognition is the motivational basis of morality and therefore decides the content of morality demands that the relationship be sufficiently broad and abstract. In other words, the relationship should not be beneficial only to a certain group of people or limited to the actual person before me to whom I must justify my action. Therefore, the possible life we are considering can be included and should be included in this broad and abstract relationship as well. It is because the possible life, despite the fact that it does not now exist, establishes a certain type of reciprocity with

\footnotetext{
${ }^{2}$ See also Kumar's application of Scanlon's contractualism to the issue of the non-identity problem. This article is indebted to his previous contribution in many ways. Especially on two premises in section 2, and on the legitimate expectation in section 4, I draw on his analysis $\operatorname{much}(4)$.

${ }^{3}$ Hereinafter I will call all possible future people "possible life." That category ranges from a mere possible "being," someone who does not exist as fetus or as embryo, to someone in the early stage of human life who cannot yet be called a person
} 
us. Consider the conditions for the relationship of mutual recognition. If mutual recognition and agreement on principle are to adequately describe the moral system, they must include an explanation of the process by which new members are continuously invited into the relationship. Because the moral contract cannot subsist as a one-time agreement among adult human beings who will someday die, the invitation of new members is a necessary part of the contract. Therefore, adult moral agents should show respect toward new members of the moral relationship even when they do not have the same capacity for rational assessment and self-governance. This invitation is mutually beneficial. For new members like possible life who will later understand this contract, equal treatment with respect is provided. For existing members like us, adding new members to the moral relationship is beneficial because it allows the expectation that the morality we construct will persist in the future, even after our death, and the expectation supports our own, current moral system(6:15-50). Hence, recognizing a possible life as a participant in morality and preparing justification for our actions toward him or her, as morality requires, are beneficial not only to the possible life but also to living people. Considering this reciprocity, it is reasonable to include possible life in the moral relationship of mutual recognition, where the morality of right and wrong are demarcated in the broad scope of morality. Thus, the right action that is required in this relationship is to act justifiably rather than simply refraining from doing harm. Therefore, we do not have to be preoccupied with the comparative conception of harm and the condition of fixed identity. As a result, we can be free from the non-identity problem.

If we depend on justifiability when we judge the morality of reproduction, then it is clear that the reproductive agent is required to justify one's reproductive act to others. Here, a possible life, which could be created by the reproductive act, is definitely included in others. It is worthwhile to note that in Scanlon's moral contractualism, there are two others whom one considers when one tries to act morally(5:202-206). First are those to whom the agent owes justification; in our investigation on reproductive ethics, the possible life.
Second are those who decide whether the candidate moral principle should be rejected or not; in our investigation, every moral agent who can be described as taking a broader and abstract perspective. So moral contractualism demands that a reproductive agent justify reproduction to the first others - the possible life-using the principle that could not be reasonably rejected by the second others - every moral agent who is motivated to find the moral principle which could not be reasonably rejected. This distinction of two others enables us to prepare an answer that is reasonably acceptable to both the possible life that does not yet exist and every moral agent.

The basic setting of justification, which is the relationship, not only resolves the non-identity problem, as shown, but also defines the contents of actions that can be justified. Let's imagine how the justification would happen for a reproductive act. The justification will be preparatory by its very nature because the possible life who will receive the justification does not exist when the act of reproduction is performed; the possible lives might ask later when they achieve ability to ask, "why did you bring me here?" Preparing the future answer and acting accordingly are the immediate requirements for the justification. For example, if an agent concludes that she cannot justify to a possible life her act of creating that life, then she is required to forgo the act of reproduction. Alternatively, a potential reproductive agent may conclude that the creation of a new human being can be justified in the given situation. Then the agent would feel prepared to answer the future question to a possible life. However, the agent would also recognize that one cannot justify any reproductive action only with a one-time positive conclusion in a hypothetical dialogue, since the determination of the act's justifiability would require several conditions to be met, such as guaranteeing qualified childrearing, abstaining from harmful acts during pregnancy, and believing that positive life conditions will be available for the possible life considering all factors related to the potential parent and the future society. If the agent arrives at a positive conclusion while assuming several conditions should be met in the future, this leads to prospective responsibility; she must satisfy the conditions if the satisfaction is up to her. 


\section{Reproductive responsibility}

I would like to propose the term "reproductive responsibility" to conceptualize the moral obligation I described above, which is the obligation to prepare and live by the future answer to possible life. Reproductive responsibility is apt word for the purpose because its Hebrew/Jewish etymological origin, the word responsibility, contains the concepts discussed in the previous section, about moral contractualism; answering to other(s) in a relation(7). Moreover, the word has the nuance of preparing for the future encounter. It is because the archetype of responsibility in Hebrew/Jewish tradition has been of course preparing an answer for the day of final judgment(7). Therefore the term, reproductive responsibility, can convey the idea of preparing an answer to possible life even though possible life is not before us now.

Viewed in light of the etymological nuance of responsibility, reproductive responsibility expects us to participate in a dialogue with possible life. But how can one participate in a dialogue with someone who does not yet exist and imagine the response? Through the hypothetical dialogue, one can still prepare her answer beforehand relying on the judgment of generic reason that possible life would have in her position. Scanlon explains that generic reasons are "reasons that we can see that people have in virtue of their situation, characterized in general terms, and such things as their aims and capabilities and the conditions in which they are placed" (5:204), while Kumar, when he applies Scanlon's moral contractualism to reproduction, uses the term, "legitimate expectation" (4), showing more explicitly the link between what one is entitled to and the relationship in which one stands. In the relationship between the reproductive agent and the possible life, the position in which possible life stands is that of a future child. Therefore, the possible life is entitled to what can be legitimately expected in that position. As Kumar correctly points out, it does not matter exactly who the child would be - the individual identity - in that position. What matters in deciding generic reason or legitimate expectation is the characterization of the situation, including the position in the relationship. Once again, when we imagine a dialogue in a relationship, non-identity is not a problem anymore.
Reproductive responsibility arises when we try to respond to the possible life, based on the relationship between reproductive agent and possible life. This interpretation of reproductive responsibility leads the agents to prospective responsibility which embraces the full range of parenthood, not limited to the retrospective responsibility concerning the harm to possible life. There have been attempts to explain reproductive responsibility or parental responsibility in retrospective way $(8,9: 103-127)$. In this explanation, reproductive/parental responsibility arises as a result of the reproductive agent's engendering harm. ${ }^{4}$ This is the way of understanding the concept of responsibility largely in terms of what an agent is responsible for. If one understands reproductive responsibility in this way, a possible life or newborn is primarily seen as a product of reproductive acts. The problem in this approach is that when the responsibility is understood to have arisen from the harm, and therefore retrospectively, the scope of responsibility is so minimalistic that it cannot embrace all the actions and attitudes parents will do and show toward their children during their lifetime. If one restores the etymological meaning of responsibility, which is a dialogue in a relationship, then being responsible always means responsible to someone. In this way of understanding, a possible life is seen as one to whom a reproductive agent(s) owes justification. The strong point of this way of understanding of reproductive responsibility is that one can embrace the full range of what parents are expected to do for their children. Since the legitimate expectation is drawn from the position in the relationship which the possible life will occupy, its range is broad enough to include all aspects of adequate rearing. Here, we can see the significant link between reproductive responsibility and parental responsibility or obligation which female commentators have long pointed out $(10,11)$. The various aspects of responsibility that are included in the role of parent cannot be sufficiently explained by responsibility for the harm done. What is required to describe the actual psychology of reproductive agents is responsibility to possible life, in other words, preparing the answer and living by the answer. In this chapter I tried to define

${ }^{4}$ The harm includes death and other negative events that are inevitable in life and the potential harm that can occur if there is no adequate care and rearing from parents. 
an obligation in reproductive ethics by using the term reproductive responsibility, in an attempt to apply a contractualist framework to the morality of right and wrong to questions of reproductive ethics. I believe that this approach helps us to decide right and wrong though the test of justifiability toward the possible life. Eventually the test should be applied also to the policy of ART subsidy.

\section{Implications of the policy of subsidizing re- productive technology}

Despite a total of more than 728 million USD poured to the subsidy program since 2006 to 2017(12-16), the birth rate has not increased significantly; total fertility rate in 2006 was 1.12 and was 1.17 in 2016(17). Why did increased access to medical technology not remedy the low birth rate? Could the concept of reproductive responsibility explain and diagnose the phenomenon? I believe so. Lack of capability(18) to rear children may contribute to the low birth rate in Korea. Since people believe they should practice reproductive responsibility, the instruction discouraging reckless reproduction when one cannot prepare the just answer to possible life, they wouldn't have reproduced. The subsidy program only shows government's urgency but does not provide individuals with a reliable resource for capability to rear one's child. Accordingly, the policy is bound to be ineffective at raising the birth rate. It is noteworthy that capability depends on the context. Capability to rear a child may differ depending on macro/micro level societal structure and people's belief inside that structure. With this understanding of capability, one can see why in Korea, despite a per capita GDP in excess of 25,000 USD, people still feel they do not have enough resources to rear a child. Gender inequality in the workplace is a serious problem in Korea despite the high rate of higher education among women. When companies and institutions do not provide equal opportunity, begetting, bearing, and rearing one's child becomes more burdensome to women. Privatization of social welfare services such as daycare are also an obstacle to parenthood. Pressure on parents to elevate their children's class and status in society further compounds the problem; because class elevation through higher education is common in East Asia, excessive investment in children's education has become a norm for many people. This has reached the point where average child rearing expenses through college graduation exceed 230,000 USD(19) per child. Considering per capita GDP, this is definitely a great burden. Moreover, unlike in the past, even a college degree does not guarantee a decent life. As economic growth has slowed, an individual's efforts cannot make as dramatic change in class as was possible in the past. This gloomy perspective gets worse with people's feeling of insecurity. This pessimism and anxiety towards the future adds to the burden of being a parent. Sadly, since potential parents of today are the ones who were raised with excessive investment from their parents, they tend to stick to the high standard of being parents; they see themselves as having a responsibility to guarantee their children a decent life as their parents did for them. Therefore, even with relatively high GDP - much higher than that of the previous generation--people see themselves as incapable of being good parents. We can recognize that reproductive responsibility is a real factor to potential parents in this omnishambles. People hesitate to have a child because they feel unequipped to answer the question why they brought this possible life into existence. They know their child may not be happy in this world. They know what they must accomplish as parents but they also know they cannot. Making people physically able to become parents does not solve the problem.

Thus far, I have argued that the current low birth rate in Korea may be the result of the lack of capability to rear children. And I have argued that in this situation, abstaining from unjustifiable, or at least questionable, act of having a baby is a reasonable way of exercising reproductive responsibility. If so, what are the ethical and policy implications of the subsidy program? Now I will argue that since the policy essentially ignores reproductive responsibility - both that of individuals and of the government itself - the policy is not only inefficient and but also ethically wrong.

First, the program ignores potential parents' reproductive responsibility. The subsidy program has been ineffective because it did not reflect an understanding that people would not be mobilized with medical support only. Since it does not help people believe that they are capable of 
fulfilling reproductive responsibility, increasing accessibility to ART cannot significantly increase the birth rate. Although the program is intended to mobilize as many childbearing age couples as possible, only those having a medical need and sufficient resources to prepare justifiable answer to possible life actually responded. Since this policy was conducted with taxpayers' money, its misguided targeting and resulting inefficiency are blameworthy. However, the policy deserves even more criticism based on its inadequate attitude toward citizens. The policy ignored the fact that potential parents bear reproductive responsibility and in so doing, treated them as a mere means to an end. Because the policy views women merely as reproductive agents, it fails to take into consideration women's decision making process in having children. Bioethics should resist this policy and reaffirm that citizens deserve respect. Respecting a person requires recognizing his or her "reason-assessing and self-governing (5:106)" capacity. Where possible reproduction is concerned, it requires not reducing potential parents to their reproductive function but to the unique perspectives and moral obligations that motivate them as future parents. While the government does not recognize the importance of this, potential parents already consider reproductive responsibility as their moral obligation. As they endure this disrespectful treatment by the government, people do not respond to the subsidy program.
Second, by neglecting the government's reproductive responsibility, the subsidy program also shows a lack of concern for possible life. Although government itself does not physically beget and bear a child, it creates the conditions in which children are born. Therefore, government bears its own reproductive responsibility, in its unique form. More specifically, government has a duty to treat people with respect and, in so doing, invite the new generation to a moral society. However, the Korean government failed to carry this reproductive responsibility as its subsidy policy lacked the research into the welfare of possible life, such as follow-up health care for newborns from the program(1). Treated only as a statistics in the target birth rate or as a solution to the current problem, possible lives are deprived of the opportunity to be respectfully invited into a moral society where they will contribute to continuity and stability. To summarize, the subsidy program not only has failed to raise the birth rate, as a matter of reproductive responsibility it is also morally unjustifiable.

\section{Conclusion}

In this article, I conceptualize reproductive responsibility as an obligation to justify, to the new life him/herself, the decision to bring new life into world. This study was conducted to clarify and justify my opposition to both the Korean government's policy of subsidizing ART and to the attitudes underpinning the policy. Although the policy largely regards women and future generations as instruments for increasing the birthrate, the non-identity problem has rendered it difficult to criticize the policy based on considerations related to future generations. My conceptualization of reproductive responsibility resolves this problem and leads to mutual recognition. I believe that this concept is consistent with O'Neill's accurate understanding of the importance of the intention to "beget, bear, and rear" a child in the act of reproduction(10), and also clarifies the factors that most women actually consider important when contemplating the issue of reproduction. 
The assisted reproductive technology subsidy in Korea - Claire Junga Kim

\section{References}

1. Ha JO. The effects of legislation on the regulation of ART: focusing on the establishment of a registry and reducing the number of embryos transferred. Bioethics Policy Studies 2016; 9(3): 103-131.

2. Kim MH. Status and Problems of the National Supporting Program for Infertility Couples. Presented at the Korean Ministry of Health and Welfare. A panel discussion for the improvement of the National Supporting Program for Infertility Couples. Symposium, Seoul, November 26, 2013.

3. Parfit D. Reasons and persons. Oxford: Oxford University Press; 1984.

4. Kumar R. Who can be wronged? Philos. Public Aff. 2003; 31(2): 99-118.

5. Scanlon T. What we owe to each other. Cambridge: The Belknap Press of Harvard University Press; 1998.

6. Scheffler S. Death and the afterlife. New York: Oxford University Press; 2013.

7. Moran G. A grammar of responsibility. New York: The Crossroad Publishing Company; 1996.

8. Shiffrin S. Wrongful life, and procreative responsibility. Legal Theory 1999; 5(2): 117-148.

9. Archard D. The obligation and responsibility of parenthood. In: Archard D, Benatar D, eds. Procreation and parenthood: The ethics of bearing and rearing children. Oxford: Oxford University Press; 2010.

10. O’Neill O. Begetting, bearing and rearing In: O’Neill O, Ruddick W, eds. Having children: philosophical and legal reflections on parenthood: essays. New York: Oxford University Press; 1979.

11. Steinbock B. Reproductive rights and responsibilities. The Hastings Center Report 1994; 24(3): 15.

12. Ministry of Health. A study for the improvement of Sub-fertility Couple Supporting Program. Seoul; 2013

13. Ministry of Health, Korea Institute for Health and Social Affairs. Analysis and evaluation of the improvement of Subfertility Couple Supporting Program 2014. Seoul; 2014.

14. Ministry of Health. Guide for maternal and child health program 2015. Seoul; 2015.

15. Ministry of Health. Guide for maternal and child health program 2016. Seoul; 2016.

16. Ministry of Health. Guide for maternal and child health program 2017. Seoul; 2017.

17. Statistics Korea. Official statistics 10103. Final results of birth statistics in 2016. Available from: http://kostat.go.kr/portal/ eng/pressReleases $/ 1 /$ index.board?bmode=read\&aSeq $=363582$.

18. Sen A. Development as freedom. New York: Anchorbooks; 1999.

19. Kim SG. Study on the limits of parental responsibility and child rearing expenses in Korea. Health Welfare Issue \& Focus 2010; 68: 1-8.

Received: April 1, 2018

Accepted: June 21, 2018 